Marquette University

e-Publications@Marquette

Theology Faculty Research and Publications

Theology, Department of

$1-1-2007$

\title{
Theology from a Fractured Vista: Susan Neiman's Evil in Modern Thought
}

Philip J. Rossi

Marquette University, philip.rossi@marquette.edu

Accepted version. Modern Theology, Vol. 23, No. 1 (January 2007): 47-61. DOI. (c) 2007 Blackwell. Used with permission. 
NOT THE PUBLISHED VERSION; this is the author's final, peer-reviewed manuscript. The published version may be accessed by following the link in the citation at the bottom of the page.

\title{
Theology from A Fractured Vista: Susan Neiman's Evil in Modern Thought
}

\author{
Philip J. Rossi \\ Department of Theology, Marquette University \\ Milwaukee, WI
}

\begin{abstract}
Evil in Modern Thought, Susan Neiman's account of the intellectual trajectory of modernity, employs the trope "homeless" to articulate deep difficulties that affirmations of divine transcendence and of human capacities to acknowledge transcendence face in a contemporary context thoroughly marked by fragmentation, fragility, and contingency. The "hospitality" of the Incarnation, which makes a fractured world a place for divine welcoming of the human in all its contingency and brokenness, is proposed as locus for theological engagement with Neiman's appropriation of a Kantian sense of hope as the readiness to resist evil in a world seemingly bereft of welcome.
\end{abstract}

The fact that the world contains neither justice nor meaning threatens our ability both to act in the world and to understand it. ${ }^{1}$

We proceed on the assumption that the true and the good, and just possibly the beautiful, coincide. Where they do not, we demand an account. The urge to unite is and ought stands behind every creative endeavor. Those who seek to unite them by force usually do more

Modern Theology, Vol 23, No. 1 (January 2007): pg. 47-61. DOI. This article is @ Blackwell Publishing, Ltd. and permission has been granted for this version to appear in e-Publications@Marquette. Blackwell Publishing, Ltd. does not grant permission for this article to be further copied/distributed or hosted elsewhere without the express permission from Blackwell Publishing, Ltd. 
harm than they set out to prevent. Those who never seek to unite them do nothing at all. ${ }^{2}$

. . . the modern world shows itself at once powerful and weak, capable of the noblest deeds or the foulest; before it lies the path to freedom or to slavery, to progress or retreat, to brotherhood or hatred. Moreover, man is becoming aware that it is his responsibility to guide aright the forces which he has unleashed and which can enslave him or minister to him. That is why he is putting questions to himself. ${ }^{3}$

\section{Evil: The Fractured Landscape of Modern Philosophy}

Written in stunningly elegant prose, Susan Neiman's Evil in Modern Thought: An Alternative History of Philosophy makes a provocative case for two theses that I believe merit careful attention in efforts to read "the signs of the times" in hope of rendering theologically intelligible the cultures of modernity and their aftermath. The first thesis makes a claim about the fundamental intellectual trajectory of modernity that disputes the "picture of modern philosophy as centered in epistemology and driven by the desire to ground our representations". ${ }^{4}$ In place of this standard narrative of a philosophical quest for foundations on which to rest cognitive certainty, Neiman proposes that "the problem of evil is the guiding force of modern thought". ${ }^{5}$ She argues that "as an organizing principle for the history of philosophy, the problem of evil is better than alternatives. It is more inclusive, comprehending a greater number of texts; more faithful to their authors' stated intentions; and more interesting. " ${ }^{6}$ Her second thesis then articulates what gives the problem of evil its conceptual and practical "traction"-i.e., what makes our grappling with evil the point at which "ethics and metaphysics, epistemology and aesthetics meet, collide and throw up their hands". 7 Neiman's thesis here-not a modest one-is that "[a]t issue [in the problem of evil] are questions about what the world must be like for us to think and act within it ${ }^{8}$. . . . it is fundamentally a problem about the intelligibility of the world as a whole." ${ }^{\prime 9}$ Not only is she straightforward about the ineluctably metaphysical character of the problem of evil-"when the world is not as it should be, we begin is

Modern Theology, Vol 23, No. 1 (January 2007): pg. 47-61. DOI. This article is @ Blackwell Publishing, Ltd. and permission has been granted for this version to appear in e-Publications@Marquette. Blackwell Publishing, Ltd. does not grant permission for this article to be further copied/distributed or hosted elsewhere without the express permission from Blackwell Publishing, Ltd. 
ask why"; ${ }^{10}$ she goes so far as to describe metaphysics as fundamentally indexed to the problem of evil: It is "the drive to make very general sense of the world in the face of the fact that things go intolerably wrong". ${ }^{11}$

Neiman builds the case for the first thesis on an astute remapping of texts from Leibniz to Rawls. In place of terrain traditionally apportioned among rationalists and empiricists on the farther side of the Kantian critical divide, with the major post-Kantian settlements eventually deployed into foundationalist and antifoundationalist camps, she offers a line of demarcation traced by reference to the problem of evil along which to place philosophers of the modern and nascent post-modern eras. ${ }^{12}$ On one side are those for whom "morality demands that we make evil fully intelligible"; ${ }^{13}$ Leibniz, Pope, Rousseau, Kant, Hegel and Marx stand here. On the other side are "those for whom morality demands that we don't"; ${ }^{14}$ here stand Bayle, Voltaire, Hume, Sade, and Schopenhauer. She recognizes that there are important figures-notably Nietzsche and Freud-who don't neatly fall in place on either side of this line. Nietzsche, on his part, shows a stubborn allegiance to both camps, ${ }^{15}$ while Freud denies the distinction between natural and moral evil, which took firm hold on the intellectual terrain in the aftermath of the Enlightenment's paradigm marker of evil, the Lisbon earthquake of 1755. ${ }^{16}$ Neiman argues that our own contemporary paradigm marker of evil, Auschwitz, has fully shattered not only this distinction-which provided much of the energy for modern religious and secular theodicies-but all other conceptual resources deployed for dealing with evil since the Enlightenment. ${ }^{17}$ Following Levinas, she argues that "Auschwitz destroyed two central responses to evil that can be viewed as secular theodicies."18 The first response (Hegel's) "sought to redeem particular evils by placing them in history"; the second (Nietzsche's) "argued that the problem of evil is our own creation". ${ }^{19}$

Yet overturning Hegel and Nietzsche provides little comfort for those who may have thought that placing the full responsibility for evil on human intent had decisively banished theodicy: "Auschwitz [also] undermined the modern rejection of theodicy that locates evil in intention." ${ }^{20}$ In short, even as "Auschwitz threatens to undermine the modern determination to live without theodicy . . . it devastated modern attempts to replace it". ${ }^{21}$ Neiman's account of philosophy

Modern Theology, Vol 23, No. 1 (January 2007): pg. 47-61. DOI. This article is C Blackwell Publishing, Ltd. and permission has been granted for this version to appear in e-Publications@Marquette. Blackwell Publishing, Ltd. does not grant permission for this article to be further copied/distributed or hosted elsewhere without the express permission from Blackwell Publishing, Ltd. 
undertaken in the shadow of Auschwitz is thus cast in terms of a reflection on the claim made by Levinas that "[p]erhaps the most revolutionary fact of the twentieth century consciousness . . . is the destruction of all balance between explicit and implicit theodicy of Western thought". ${ }^{22}$ She seeks to construe this claim in the light the fact that "elements of traditional discussion of the problem of evil have reemerged in response to Asuchwitz". ${ }^{23}$ She thus offers a sketch of the efforts of thinkers she considers representative of post World War II philosophy-Camus, Arendt, Adorno and Horkheiemer, and Rawls-to grapple with questions of evil even though they do so "in painful awareness that even the attempt to voice them may be problematic". ${ }^{24}$

In her narration of this "alternative history", Neiman is candid that her sympathy lies with those who take morality to demand that we persist in efforts to make evil intelligible rather than acquiesce in its unintelligibility. In professed alliance with Kant, she locates this moral demand for making evil intelligible as a function of our rationality. Making sense of the world-even when it resists our efforts-is fundamental for our human dealings with the world. "We are so structured as to expect a world that comes to meet us halfway, for we cannot make meaning alone. . . . Belief that there may be reason in the world is a condition of possibility of our being able to go on in it." 25 In the face of this tenacious demand on our part for intelligibility, evil (as Dostoevsky recognized) "is not just one more mystery. It is so central to our lives that if reason stumbles there, it must give way to faith. ${ }^{26}$ At stake in efforts to contend with and comprehend evil is the integrity of the demand for intelligible meaning that powers human inquiry: "The smaller the expectations of the rational, the less it demands of the real. Where reason's demands are too humble, it concedes all the terms to reality before the struggle begins. "27 Of greater significance is the fact that the integrity of efforts to resist evil also is at stake: "To abandon the effort to comprehend evil is to abandon every basis for confronting it, in thought as in practice. . . . Belief that the world should be rational is the basis of every attempt to make it so. . . . Without such a demand, we would never feel outrage-nor assume the responsibility for change to which outrage sometimes leads." 28

Much useful discussion could ensue from placing Neiman's larger mapping of modernity and its aftermath-as well as her location of 
Leibniz, Rousseau, Kant, Hume, Nietzsche, et al., within it-in conversation with other accounts that theologians have been using (or disputing) in efforts to limn the contours of the intellectual and cultural dynamics of the last three centuries of modernity. My hunch is that engaging her work with that of Charles Taylor, Michael Buckley, George Steiner and Louis Dupré, who, like her, acknowledge and appreciate the achievements of a modernity whose flaws they do not hesitate to name and criticize, could provide an especially productive interchange. That project, however, is well beyond the more limited scope of this essay, which is to initiate a theological engagement with her second thesis and its provocative articulation of the intellectual and moral dynamics that place the question of evil at the center of modern philosophical inquiry. This thesis takes evil to bring into fundamental question the unbreakable connection that our human efforts to make sense of the world forge with our hope of being at home in the world. As she puts this point in more abstract terms, "ethics and metaphysics are not accidentally connected. Whatever attempts we make to live rightly are attempts to live in the world."29

The connection between "making sense of the world" and the hope it elicits for "being at home in the world" thus provides an initial locus for conversation with Neiman's thesis. This connection is at the root of her explicit displacement of "theodicy"-construed as "justifying God"-from the center of discussion of the problem of evil, and its replacement by the "principle of sufficient reason"-construed as a "question of intelligibility: Are our capacities to find and create meaning in a world adequate to a world that seems determined to thwart them?"30 My interest in this dimension of her thesis is not primarily in her treatment of theodicy as a (distinctively) modern enterprise, even though the details of her discussion add further weight to a general claim about the "end of theodicy" for which others have already built a strong case. ${ }^{31}$ My main interest, rather, is in her description and assessment of "the impulse to theodicy", 32 which she had earlier described as "the need to face evil in the world without giving in to despair". ${ }^{33}$ She claims that "the impulse to theodicy is not a relic of monotheism, but goes deeper than either"; that in this impulse "something beside God is at issue"; that the source of this impulse is "something deeper than religion". ${ }^{34}$ It is "deeper than religion" inasmuch as this impulse lies in something about the structure of what makes us human from which religion-but not only

Modern Theology, Vol 23, No. 1 (January 2007): pg. 47-61. DOI. This article is @ Blackwell Publishing, Ltd. and permission has been granted for this version to appear in e-Publications@Marquette. Blackwell Publishing, Ltd. does not grant permission for this article to be further copied/distributed or hosted elsewhere without the express permission from Blackwell Publishing, Ltd. 
religion-arises: "the drive to seek reason in the world-even, or especially, at the points where it seems most absent-is as deep a drive as any we have". ${ }^{35}$

Neiman's reading of the principle of sufficient reason that drives the impulse to metaphysics-and, with it, the impulse to theodicy-is, as she readily admits, an articulation of her understanding of Kant's account of reason. She takes the principle of sufficient reason to "express the belief that we can find a reason for everything that the world presents" and calls it a "regulative principle . . . a drive essential to reason itself". ${ }^{36}$ Of equal significance is the fact that she sees the dynamism of this principle functioning in terms of reason's capacity for setting ends in the world, which "is a matter of seeking, and creating, what is good in itself". ${ }^{37}$ From this she concludes that what "Kant implied, but never actually stated, behind the principle of sufficient reason itself is the assumption that the is and the ought should coincide. The principle of sufficient reason starts its work where they fail to meet." 38 More so than many Kant scholars of a previous generation, Neiman gives full weight to Kant's claim that there is a unity to the theoretical and practical uses of reason and to his assignment of primacy to its practical (moral) use. ${ }^{39}$ In so doing, she inverts two dominant philosophical stances of the twentieth century: The eschewal of metaphysics and the separation of metaphysics from ethics. She affirms, in contrast, that philosophy must engage metaphysical questions and that the most important question of all, the question of evil, is precisely where metaphysics and ethics ineluctably connect: "The problem of evil can be expressed in theological or secular terms, but it is fundamentally a problem about the intelligibility of the world as a whole. Thus it belongs neither to ethics nor to metaphysics but forms a link between the two." 40

\section{Theology: Fractured Vistas upon a Fractured Landscape?}

Against this background, one possible way for a Catholic theology to read Neiman's claims about the tenacious human demand for making sense of the world would be to engage it with the claims about human intellectual dynamism that have been advanced in the tradition of transcendental Thomism. That dynamism, identified as a 
"drive toward being" that is a fundamental marker of the spiritual dimension of our human reality, serves as a crucial conceptual grid from which transcendental Thomism sought to align what otherwise appear to be quite disparate Augustinian, Thomist and Kantian accounts of human cognitive capacities and structures. This kind of engagement with Neiman's robust account of the regulative function of reason in the human quest for making sense of the world in which we must live, might open new lines of useful conversation on a fundamental anthropological question that need to be faced in the aftermath of modernity: What gives us warrant to speak of the human as "spiritual"?

As helpful and as important as that conversation might be, however, I think a more urgent and challenging locus for discussion lies in engaging her account of the conceptual and cultural contexts in which the "impulse to metaphysics" now functions, and upon which any effort to make sense of the world in the hope of being at home in the world now must bear. I believe this discussion has more urgency because her account of this context articulates deep difficulties that affirmations of divine transcendence and of corresponding human capacities to acknowledge that transcendence need to face in a contemporary human context that is so thoroughly marked by the fragmentation, fragility, and contingency she poignantly describes. As I will suggest in the final section of this essay, the very fractured and fragile character that she takes to mark our human finitude may offer a particularly apt locus for a post-modern theological re-appropriation of the scope and import of God's incarnate engagement with the human.

Two passages from the concluding paragraphs of Evil in Modern Thought-along with the title of the final chapter, "Homeless"-can serve as appropriate points of reference for opening this line of discussion:

If the events that determined the twentieth century left contemporary experience fractured, any conception of reason that can be salvaged must reflect fracture itself. . . . What binds the real and the rational together must be so fragile that it will seem miraculous-and on occasion the miracle occurs. As with any other miracle, it takes something like faith to perceive it. ${ }^{42}$ 
If I am reading Neiman correctly, the landscape of a post-Auschwitz world presents itself as bleak, stark and abidingly fragmented. Not only do we live and act in a world of nature that we have fully disenchanted of purposes that pay special attention to humanity; we live and act in a world in which we have become acutely aware of how thoroughly capable we have become of disenchanting and disengaging ourselves from attention to our own humanity. It is not just the landscape in which we find ourselves that has fragmented; something fundamental about ourselves, in ourselves, has deeply fractured. She notes that "Auschwitz revealed the remoteness of humans from themselves"43 and later adds that "Auschwitz was conceptually devastating because it revealed a possibility in human nature that we hoped not to see". ${ }^{44}$ This possibility is one that Hannah Arendt sought to capture in her phrase "the banality of evil", which Neiman-in defending it against critics of Arendt-sees as bearing the profoundly unsettling insight that "[I]n contemporary evil, individuals' intentions rarely correspond to the magnitude of evil individuals are able to cause." 45

These remarks, offered in the context of her discussion of the "devastation" of our conceptual resources for dealing with evil in the aftermath of Auschwitz, are ones that I propose that we read in the light of what she articulates in the introduction as one guiding interest for her inquiry:

Since I do not think an intrinsic property of evil can be defined, I am, rather, concerned with tracing what evil does to us. If designating something as evil is a way of marking the fact that it shatters our trust in the world, it's that effect, rather than the cause, which I want to examine. It should follow that I have even less intention of solving the problem of evil than I do of defining evil itself. My interest is, rather, to explore what changes in our understanding of the problem of evil reveal about changes in our understanding of ourselves, and of our place in the world. ${ }^{46}$ [Emphasis mine.]

Out of philosophical texts from Bayle to Rawls, Neiman has pieced together a complex mosaic of changes that have taken place in how Western intellectual culture has understood the problem of evil. Embedded within that mosaic-though not always as strongly highlighted-are changes she sees correlatively taking place in the 
understanding of ourselves. In hope of gaining clarity on the latter changes, even at the risk of reducing her mosaic to a cartoon outline, I propose making just one of the former changes a focus of attention. This change-which is no small one-displaced God from the center of efforts to render evil intelligible and it put humanity in God's stead. "The problem of evil began by trying to penetrate God's intentions. Now it appears that we cannot make sense of our own." ${ }^{\prime 47}$ What started out as the audacity of Kant's categorical imperative of universalizing maxims by imagining ourselves as creators of a law of nature-"the fantasy of replacing God is the test by which morality is decided"48_ has ended with the disorientation attendant upon our moral helplessness in the face of the evil marked by Auschwitz: "the forms of evil that appeared in the twentieth century made demands modern consciousness could not meet." 49

What drove attempts to render evil intelligible from a probing of God's purposes to a shattering of our own? Neiman traces its sources back to the interplay of two key distinctions: the first is that between creation and the creator; the second is that between natural evil and moral evil. The project of theodicy as a defense of God's purposes had traditionally depended on being able to distinguish between the creator and creation-and firmly placing our capacities for understanding either one within the finite limits of our status as creatures. Neiman argues that, prior to Lisbon, the way this first distinction had been embedded in the pre-modern world view posed no significant threat to affirmations of the goodness of either the creator or creation; on the contrary, "[o]ur lack of understanding of why the gods struck can be one more sign of the distance between the human and the divine that moves some souls to reverence. ${ }^{\prime 50}$ After Lisbon (and following Rousseau), however, theodicy offered in defense of the goodness of the creator-as well as much of the criticism of such a defense-could continue only as it also engaged the further distinction between natural evil and moral evil that offered "two messages: we should worry about the evils for which we are responsible and God will take care of the rest". ${ }^{51}$

Both distinctions, however, became more problematic for both defenders and opponents of the theodicy as that project moved through the nineteenth century: A God whose relation to creation is either withdrawn into the remoteness of general Providence or 
immanentized into the dialectic of history comes, in the end, to be little different from a God dethroned by a Promethean humanity. Comprehending evil in a creation without God might thus seem a simpler problem, but it has proved no less intractable in the wake of the breakdown of the distinction between natural and moral evils. In a world in which scientific inquiries have disenchanted us from seeing the operation of supernatural agencies, this distinction had functioned as the trusted conceptual tool to divide human moral responsibility for evil from the human misfortune that ensues in consequence of floods, storms, and earthquakes. Yet this disenchantment also rendered disastrous events in the natural world so ordinary as to be "literally insignificant-not representative of something besides themselves, nor signals we need to decode". ${ }^{52}$ The distinction between natural evil and moral evil that seemingly tamed the world by voiding natural disaster of moral significance proved to be unstable: It is not merely the case that "[s]ince Lisbon, natural evils no longer have any seemly relation to moral evils"; it is rather that "they no longer have meaning at all". ${ }^{53}$ On Neiman's reading of intellectual history, Freud then provides the final arguments for a relentless naturalism that reveals how stripped of all comfort the disenchanted world must be. As she remarks at the conclusion of her discussion of Nietzsche and Freud, "Science may have abolished the sense that the world is inhabited by forces with wills of their own, and in this way reduced the unheimlich. But the price is enormous, for all nature stands condemned. Human beings themselves become walking indictments of creation." 54

Much in Neiman's account of this distinction, its destabilization, and its relation to the distinction between creator and creation is worthy of extensive discussion. Constraints of space permit treatment of just one of its features - the one signaled in the title of her final chapter, "Homeless". This title encompasses the thoroughgoing fragility, fragmentation, and contingency of the human that Auschwitz and other evils of the twentieth century have laid bare with brutal and ever so efficient horror. In her view, the fracturing of the distinction between natural and moral evil has had its most destructive impact upon our very efforts to make sense of the world in which those evils took place, and, more pointedly, to make sense of our own place in that world:

Modern Theology, Vol 23, No. 1 (January 2007): pg. 47-61. DOI. This article is @ Blackwell Publishing, Ltd. and permission has been granted for this version to appear in e-Publications@Marquette. Blackwell Publishing, Ltd. does not grant permission for this article to be further copied/distributed or hosted elsewhere without the express permission from Blackwell Publishing, Ltd. 
Like Lisbon, Auschwitz acquired significance in relation to the web of beliefs in which it occurred. What seem devastated-nay, entirely thwarted-by Auschwitz was the possibility of intellectual response itself. Thought stood still, for the tools of civilization seemed as hopeless in coping with the event as they were in preventing it. ${ }^{55}$

Our "conceptual helplessness" is all the more devastating because it extends to ourselves. We find ourselves homeless in a world we had trusted to be fundamentally "for" us-not simply in the sense of being there for our use, or even there for our comfort, but in the sense of "meeting us halfway" by yielding meanings responsive to the deep longing for "making sense" that drives us. As modernity unfolded, we seemed to be learning how "to stop viewing the world as a home that a stern but indulgent parent might have built for us, and to grow up and build our own". ${ }^{56}$ Athwart this confidence in our growing worldly adulthood, the evils we have wrought on one another since the start of the twentieth century have deeply undercut whatever previous trust we had in ourselves to be "builders" of a home in the world. Neiman contends that instances of "single-mindedly thoughtful evil"57_such as terrorism-have not been the factors most corrosive of this trust. Far more devastating have been the routines of thoughtlessness and inattention that allow massive evil to be done by "ordinary people who do not let themselves acknowledge, exactly, what it is they do". ${ }^{8}$ She hews close to her Kantian heritage in marking the opacity of our moral self-knowledge, even as she indicates that Kant hardly foresaw in such opacity the insidious power of the banality of evil: "[i]n contemporary evil, individuals' intentions rarely correspond to the magnitude of evil individuals are able to cause". 59

As I understand Neiman's account, however, contemporary forms of evil have not themselves rendered us homeless; they have, rather, brought us to recognition of how homeless we are and how homeless we will continue to make ourselves-in the absence of resolute, unflinching resistance to evil. We may be homeless, but for all that we are not bereft of hope. In this, Neiman begs to differ with Nietzsche, for whom "[h]ope itself must be combated, since hope for something better condemns whatever there is". ${ }^{60}$ Her difference from Nietzsche is no more pointedly affirmed than in her recurring trope of the child, who provides a living icon of hope: "In the child's refusal to

Modern Theology, Vol 23, No. 1 (January 2007): pg. 47-61. DOI. This article is @ Blackwell Publishing, Ltd. and permission has been granted for this version to appear in e-Publications@Marquette. Blackwell Publishing, Ltd. does not grant permission for this article to be further copied/distributed or hosted elsewhere without the express permission from Blackwell Publishing, Ltd. 
accept a world that makes no sense lies all the hope that ever makes us start anew." ${ }^{11}$ In a Wittgensteinian mode, Neiman leaves unsaid what offers hope even as she points to acts of resistance to evil that instanced it. Of the passengers on Flight 93 who, "unlike the passengers on the other flights [on 9/11] . . . had knowledge on which they could act", 62 she comments:

... We will never know how much destruction they prevented, but we know they prevented some. They proved not only that human beings have freedom; we can use it to affect a world we fear we don't control.

This is not theodicy. It is not even consolation-though it is all the hope we have. ${ }^{63}$

Where we might go theologically from where Neiman stands, I am not sure. We may, first of all, be reluctant even to stand where she does inside such a fractured landscape. We may be even more reluctant to stand there as the fractured selves she suggests that we need to acknowledge we have all become. Possibly the most theologically disorienting-but by that measure also the most theologically challenging-feature of standing with her would be taking seriously the prospect that all our efforts to make sense of our landscape are so fragile that they will only come out as fragmented as we are: "Where experience was truly shattered, the pieces will never be neatly ordered again."64 To the extent that, as theologians, we may be also prone to what was "Kant's greatest error . . . to mistake the demand for reason with the demand for system", ${ }^{65}$ standing with Neiman might be a useful exercise in theological humility. At the same time, Neiman would expect us to make such humility also an uncompromising exercise of the steadfast demand for making sense of the fractured pieces we see and that we are. Though it may be the case that "whatever sense we find must be incomplete", that incompleteness is itself reason why "attention to the pieces is now all the more important".66

\section{Epilogue: Incarnation as God's Hospitality}

It would be unfair to present the readers of this essay with a challenge to find ways to move theologically from Neiman's prospect on this intellectual-cultural landscape without at least suggesting some

Modern Theology, Vol 23, No. 1 (January 2007): pg. 47-61. DOI. This article is @ Blackwell Publishing, Ltd. and permission has been granted for this version to appear in e-Publications@Marquette. Blackwell Publishing, Ltd. does not grant permission for this article to be further copied/distributed or hosted elsewhere without the express permission from Blackwell Publishing, Ltd. 
of the routes that I think could be explored. I have already suggested that one path that lies along directions that move toward the vantage points from which Charles Taylor, Louis Dupré, George Steiner, and Michael Buckley have surveyed the landscape of modernity and its aftermath. They each are acutely aware that on any of the paths along which we head on this terrain of fractured meaning, God and humanity have now been mutually put in question in radical, seemingly unprecedented ways. They all suggest (and Neiman, Taylor and Dupré quite explicitly affirm) that changes in the ways that we think and imagine ourselves have been efficacious-they change who we are. So to the extent that the project of modernity has placed God and humanity within a fractured landscape upon which both are mutually in question, the changes it has wrought in how we think of and imagine ourselves also have had their impact on how we think of and imagine God-and, of comparable importance, on how we think of and imagine our relation to God.

There is another important point, moreover, in which they seem to agree: Despite modernity's dynamic for enlarging the range of human instrumental control, we still cannot change ourselves into whatever we want without limit. We live within, and must continue to recognize, a fundamental recalcitrance in the contingency in the world and in our humanity that steadfastly resists the imperialism of instrumentalism. In the context of engaging the opacity of ourselves in the processes of history, society and culture that transform us and our self-understanding, these five thinkers all underscore, though in quite distinct ways, the fact that the relation between our opaque humanity and transcendence becomes unavoidably at issue. Therefore, one path to follow in this fractured terrain might lie along Neiman's location of the issue of transcendence within a relentless human determination to have the world make sense, even as its moral contingency eludes our comprehension and our control. As noted earlier, I think that along this path might lie useful conversation with the Augustinian dynamic of restless intellectual longing that was one of the engines driving transcendental Thomism and la nouvelle théologie. Along this way, Neiman's reminders about the necessity of humility and "attention to the pieces"67 may prove especially helpful for keeping that conversation mindful that it must neither bypass particularities when they become resistant to efforts to make sense of them, nor force 
them to make sense by pressing them into the conceptual and imaginative grids with which we initially encounter them.

From the tenor of my discussion in Part II, it should be evident that another related locus for theological conversation with Neiman that I think would be particularly fruitful to pursue lies in her depiction of the fragile and incomplete character of human reason's dealing with a fractured world and with our fractured selves in that world. What I find especially noteworthy for theological engagement in Neiman's treatment of our fractured reason is the sturdy sense of hope that nonetheless pervades it: Even though our efforts to make sense must rely upon so fragile a capacity, our very awareness of the fragility of reason is itself a source of hope that these efforts will not prove ultimately futile. Our drive to make sense may very well lie athwart both the workings of nature in its radical contingency with respect to our intents and purposes as well as athwart the opacity of our own moral thoughtlessness; both can undermine hope by giving us reason to take the contingently actual as an insurmountable obstacle to the morally possible.

The sturdiness of hope in the Kantian key that Neiman plays, however, consists precisely in its unwillingness, in view of what ought to be, to settle for what is. This unwillingness is neither wish, nor velleity. Like Kant, her philosophical mentor, Neiman takes the sturdiness of hope to consist in its power to keep our action faithful to the moral trajectory along which we make ought become is. Kantian hope is thus the readiness to transform what is into what ought to be. ${ }^{68}$ My interest here, however, is not simply upon appropriating Neiman's reading of Kant as a resource for a (theological) articulation of the moral power of hope. I also think that her mosaic of the fragments of our condition might provide a starting place for looking at the world from-for lack of a more felicitous phrase-the "underside" of God's incarnation into the fractured contingency that constitutes the dynamics of our human world. That "underside" is the absence of welcome, the unavailability of hospitality, encountered by God's word incarnate-an unavailability marked in human terms in Luke's infancy narrative as "no room at the inn" and in cosmic terms in John's prologue as "his own received him not". Yet this absence, unavailability, even refusal of welcome is met not by its counterpart, but by its radical inversion: The ignored, unwelcomed guest becomes

Modern Theology, Vol 23, No. 1 (January 2007): pg. 47-61. DOI. This article is @ Blackwell Publishing, Ltd. and permission has been granted for this version to appear in e-Publications@Marquette. Blackwell Publishing, Ltd. does not grant permission for this article to be further copied/distributed or hosted elsewhere without the express permission from Blackwell Publishing, Ltd. 
the welcomer, human inhospitality is reciprocated in gracious irony by a divine hospitality in which God makes the fractured world a place for divine welcoming of the human in all its contingency and brokenness.

My suggestion, therefore, about how to move theologically from within Neiman's trope of homelessness is that we focus attention on hospitality as a key marker of how our fragmented selves may steadfastly enact hope for successful traverse, despite our fragility, across the daunting character of the broken terrain of our contemporary human condition. This suggestion arises, in large measure, from the resonances that Neiman's trope of homelessness has with a motif sounded by George Steiner in his accounts of the culture of modernity. Just as Neiman takes Kant's "metaphysic of permanent rupture" to demarcate a "gap between nature and freedom, is and ought, [that] conditions all human existence" and that also "means recognizing that we are never, metaphysically, at home in the world", 69 Steiner takes the fracturing of meaning to be the defining event of modernity: "[T]he break of the covenant between word and world which constitutes one of the very few genuine revolutions of spirit in Western history, and which defines modernity itself."70 In the face of so deep a rupture, Steiner proposes that our engagement with one another, and with all that is other, on this fractured terrain requires more than ever before (now that we are in the "epilogue", the "after-word") a receptivity of mutually encountered freedom that he terms "courtesia", or "tact of heart", a receptivity he sees exhibited in "the intuition that the true reception of a guest, of a known stranger in our place of being touches on transcendent obligations and opportunities". ${ }^{71}$ Even more to the point with respect to Neiman's trope of "homelessness", he links the Jewish experience of being "an exile, an outsider" to the central importance he attaches to this fundamental enactment of receptivity in the face the whole array of dynamics in which humans make themselves complicit in the refusal of otherness: "Why have we survived? Because I believe we must teach other human beings to be guests of each other. . . . We must teach people we are guests of life on this crowded, polluted planet."72

What gives this path of exploration the character of a theological response to Neiman's depiction of the fractured terrain on which we must learn to be guests of one another comes, of course, in the recognition that the first hospitality is God's. This hospitality welcomes

Modern Theology, Vol 23, No. 1 (January 2007): pg. 47-61. DOI. This article is @ Blackwell Publishing, Ltd. and permission has been granted for this version to appear in e-Publications@Marquette. Blackwell Publishing, Ltd. does not grant permission for this article to be further copied/distributed or hosted elsewhere without the express permission from Blackwell Publishing, Ltd. 
us in all our human fracturedness, and it is in God's welcome-enacted in the Word creative and incarnate-that we are empowered to welcome each other. To Neiman's trope of "homelessness" we can, I believe, appropriately add that our condition of homelessness in a world of fractured meaning does not leave us bereft of the gifts and skills of a hospitality through which the radiance of the divine hospitality that enables us to welcome each other can be glimpsed. ${ }^{73}$

\section{Notes}

${ }^{1}$ Susan Neiman, Evil in Modern Thought: An Alternative History of Philosophy, (Princeton and Oxford: Princeton University Press, 2002), p. 5.

2 Ibid., p. 322.

3 Gaudium et Spes, § 9.

${ }^{4}$ Neiman, Evil in Modern Thought, p. 5.

${ }^{5}$ Ibid., pp. 2-3.

${ }^{6}$ Ibid., p. 7. She further elucidates how it is "more interesting": "Here interest is not merely an aesthetic category, important as that is, but also an explanatory one, which answers Kant's question: What drives pure reason to efforts that seem to have neither ends nor results?" (p. 7).

7 Ibid., p. 5.

${ }^{8}$ Ibid., p. 5.

${ }^{9}$ Ibid., pp. 7-8.

10 Ibid., p. 322.

${ }^{11}$ Ibid., p. 322.

12 Her chronological starting point is 1697 , the publication date of Bayle's

Dictionary, which she takes to mark the beginning of the Enlightenment.

13 Ibid., p. 8.

${ }^{14}$ Ibid., p. 8.

${ }^{15}$ Ibid., p. 204: "Nobody was more vehement in denying the existence of an order behind appearances, or in denouncing the attempt to find one as a denial of life. Yet nobody struggled harder against passively accepting appearances, nor warned more actively against nihilism."

${ }^{16}$ Ibid., p. 237: "The older Freud was at once the most articulate proposer of naturalism and the author of one of the darker views of human nature. It is thus little surprise that principled distinctions between different kinds of evil melt away in his work. They are all merely instances of countless ways in which life is too hard for us: the whole world presents obstacles to thwart our desires."

17 Neiman's use of Auschwitz as an exemplary marker of the exhaustion of modern conceptual resources for rendering evil intelligible does not rest upon claims about its uniqueness in the annals of mass murder,

Modern Theology, Vol 23, No. 1 (January 2007): pg. 47-61. DOI. This article is @ Blackwell Publishing, Ltd. and permission has been granted for this version to appear in e-Publications@Marquette. Blackwell Publishing, Ltd. does not grant permission for this article to be further copied/distributed or hosted elsewhere without the express permission from Blackwell Publishing, Ltd. 
be it in terms of the number of its victims, or the cruelty with which those murders were done. Cf. Ibid., p. 256: "If whatever is new about contemporary evil cannot be simply a matter of relative quantity, neither is it a matter of relative cruelty."

18 Ibid., p. 240.

${ }^{19}$ Ibid., p. 257.

${ }^{20}$ Ibid., p. 240. Neiman notes the general silence of much twentieth-century philosophy on the problem of evil. Cf. Ibid., p. 288: "If any one feature distinguishes twentieth-century philosophy from its predecessors, it is the absence of explicit discussion of the problem of evil."

${ }^{21}$ Ibid., p. 258.

22 Emmanuel Levinas, "Useless Suffering," The Provocation of Levinas, edited by Robert Bernasconi and David Wood (London and New York: Routledge, 1988), p. 161. Quoted by Neiman in Evil in Modern Thought, p. 238.

23 Neiman, Evil in Modern Thought, p. 291.

${ }^{24}$ Ibid., p. 291.

25 Ibid., pp. 233-234.

${ }^{26}$ Ibid., p. 235.

27 Ibid., p. 327.

28 Ibid., pp. 325-326.

29 Ibid., p. 327.

30 Ibid., p. 318.

${ }^{31}$ One recent lucid summary of this claim can be found in Richard Bernstein, Radical Evil: A Philosophical Interrogation (Cambridge: Polity Press/Malden, MA: Blackwell: 2002), p. 229.

32 Ibid., p. 318.

33 Ibid., p. 291.

34 Ibid., p. 318.

35 Ibid., p. 322.

${ }^{36}$ Ibid., p. 320.

37 Ibid., p. 322.

38 Ibid., p. 322.

${ }^{39}$ She provides an extensive treatment of Kant's account of reason in Susan Neiman, The Unity of Reason: Rereading Kant (New York: Oxford, 1994).

40 Neiman, Evil in Modern Thought, pp. 7-8.

${ }^{41}$ For an initial articulation of this question, see Philip Rossi, "Divine Transcendence and the 'Languages of Personal Resonance': The Work of Charles Taylor as a Resource for Spirituality in an Era of Postmodernity" in Theology and Conversation, (Bibliotheca Ephemeridum Theologicarum Lovaniensium 172), edited by J. Haers and P. DeMey, (Leuven, Belgium: Peeters Press, 2004), pp. 783-794; and "The Idiom

Modern Theology, Vol 23, No. 1 (January 2007): pg. 47-61. DOI. This article is @ Blackwell Publishing, Ltd. and permission has been granted for this version to appear in e-Publications@Marquette. Blackwell Publishing, Ltd. does not grant permission for this article to be further copied/distributed or hosted elsewhere without the express permission from Blackwell Publishing, Ltd. 
NOT THE PUBLISHED VERSION; this is the author's final, peer-reviewed manuscript. The published version may be accessed by following the link in the citation at the bottom of the page.

of Spirit: Discourse, Human Nature, and Otherness. A Response to Philip Clayton and Steven Smith" in Advents of the Spirit: Orientations in Pneumatology, edited D. Lyle Dabney and Bradford Hinze, (Milwaukee, WI: Marquette University Press, 2002), pp. 233-239.

42 Neiman, Evil in Modern Thought, p. 327.

43 Ibid., p. 240.

44 Ibid., p. 254.

45 Ibid., p. 273.

${ }^{46}$ Ibid., p. 9. This is a locus from which to engage Neiman's work with that of Charles Taylor and of Louis Dupré who each offer accounts of shifts in human self-understanding that both shape and are shaped by the contours of the cultures of modernity and their aftermath.

47 Ibid., p. 281.

48 Ibid., p. 79.

${ }^{49}$ Ibid., p. 239. She notes that one of the characteristics of modern forms of evil of which Auschwitz is emblematic is that it subjects its victims "to a process designed to destroy the very concept of humanity within them" and "to deny its victims all the conditions of having a soul" (Ibid., p. 267). She further observes that not just victims who fall prey to such destruction: "Once we turn away from Nazi crimes to look at others, we will find murders carried out for motives that many of us share. Perhaps the most frightening consequence of pondering these considerations is that the self itself retreats from view. The mass murderer turns individuals into numbered corpses, but he himself, as individual, is scarcely more present" (Ibid., p. 277).

50 Ibid., p. 246.

${ }^{51}$ Ibid., p. 55.

52 Ibid., p. 236.

53 Ibid., p. 250. Cf. Ibid., pp. 3-4: "The sharp distinction between natural and moral evil that now seems self evident was born around the Lisbon earthquake and nourished by Rousseau. Tracing the history of that distinction and the ways in which the problems refused to stay separate, is one aim of this book."

54 Ibid., pp. 236-237.

55 Ibid., p. 257.

56 Ibid., p. 305.

57 Ibid., p. 285.

58 Ibid., p. 285.

59 Ibid., p. 273.

60 Ibid., p. 307.

61 Ibid., p. 320.

62 Ibid., p. 288.

${ }^{63}$ Ibid., p. 288.

Modern Theology, Vol 23, No. 1 (January 2007): pg. 47-61. DOI. This article is @ Blackwell Publishing, Ltd. and permission has been granted for this version to appear in e-Publications@Marquette. Blackwell Publishing, Ltd. does not grant permission for this article to be further copied/distributed or hosted elsewhere without the express permission from Blackwell Publishing, Ltd. 
NOT THE PUBLISHED VERSION; this is the author's final, peer-reviewed manuscript. The published version may be accessed by following the link in the citation at the bottom of the page.

${ }^{64}$ Ibid., p. 327.

65 Ibid., p. 326.

66 Ibid., p. 326.

67 Ibid., p. 326.

${ }^{68} \mathrm{~A}$ key text for Kant's understanding of hope in this sense is the conclusion of the first part of the Metaphysics of Morals. The affirmation "There shall be no war" as a categorical imperative-as an "ought to be" that we must work for-trumps the question of actuality: "So the question is no longer whether perpetual peace is something real or a fiction, and whether we are deceiving ourselves in our theoretical judgments when we assume that it is real" Immanuel Kant, Practical Philosophy, The Cambridge Edition of the Works of Immanuel Kant, trans. Mary Gregor, (Cambridge: Cambridge University Press, 1996), p. 490.

69 Neiman, Evil in Modern Thought, p. 80.

70 George Steiner, Real Presences, (Chicago, IL: University of Chicago Press, 1989), p. 93; author's emphasis.

71 Ibid., p. 155.

72 "On Being a Perfect Guest: The Tablet Interview: George Steiner", The Tablet, August 13 (2005), p. 14.

73 I am grateful to Joseph Runzo, the participants in the Philosophy of Religion section of the College Theology Society, participants in the Enlightenment and Ethics Interest Group of the Society of Christian Ethics, members of the graduate seminar on "The Structure of Religious Experience" at Marquette University, the Fellows at the Woodstock Theological Center, Washington, DC, and the editors and referees for Modern Theology for helpful comments on earlier versions of this essay.

Modern Theology, Vol 23, No. 1 (January 2007): pg. 47-61. DOI. This article is @ Blackwell Publishing, Ltd. and permission has been granted for this version to appear in e-Publications@Marquette. Blackwell Publishing, Ltd. does not grant permission for this article to be further copied/distributed or hosted elsewhere without the express permission from Blackwell Publishing, Ltd. 